\title{
Fluctuations in algal chlorophyll and carotenoid pigments during solar bleaching in the coral Goniastrea aspera at Phuket, Thailand
}

\author{
I. Ambarsari ${ }^{1, *}$, B. E. Brown ${ }^{1}$, R. G. Barlow ${ }^{2}$, G. Britton ${ }^{3}$, D. Cummings ${ }^{2}$ \\ 'Department of Marine Sciences and Coastal Management, Ridley Building, University of Newcastle, Newcastle-upon-Tyne NE1 7RU, \\ United Kingdom \\ ${ }^{2}$ Plymouth Marine Laboratory, Prospect Place, West Hoe PL1 3DH, United Kingdom \\ ${ }^{3}$ School of Biological Sciences, University of Liverpool, PO Box 147, Liverpool L69 3BX, United Kingdom
}

\begin{abstract}
HPLC analysis of pigments of the symbiotic algae of the coral Goniastrea aspera (Verrill) showed the presence of the chlorophylls $a$ and $c_{2}$ (chl $a$ and $c_{2}$ ) and the carotenoids peridinin, diadinoxanthin, diatoxanthin and $\beta$-carotene. Increased production of diatoxanthin was seen in algae extracted from the western surfaces of corals, exposed to high levels of solar radiation, during a solar bleaching event. In addition, an increase in the ratio of diatoxanthin to the total xanthophyll pool was observed in bleached tissues, together with a progressive increase in the total xanthophyll pool (relative to total chlorophyll levels) over the bleaching period. These results support a potential photoprotective function for xanthophylls in the coral/algal symbiosis. Chlorophyll breakdown products, phaeophytin a and pyrophaeophytin $a$, were recognised in considerable quantities only in bleached tissues. Computation of a simple chlorophyll budget showed that $45 \%$ of chl a was lost in partially bleached tissues and approximately $62 \%$ in fully bleached tissues, indicating a very rapid photodegradation of chlorophyll $24 \mathrm{~h}$ after exposure to high irradiance.
\end{abstract}

KEY WORDS: Symbiotic algae Pigments - Xanthophylls . Coral B Bleaching

Coral bleaching is characterised by a loss of endosymbiotic algae, loss of algal pigmentation or a combination of the 2 processes. Pigment changes have frequently been monitored in bleached corals and are usually quantified as alterations in algal chlorophyll content (Hoegh-Guldberg \& Smith 1989, Szmant \& Gassman 1990, Fitt et al. 1993). Fluctuations in pigments other than chlorophylls have rarely been analysed in bleached corals. One exception is the work

•E-mail: ireng.ambarsari@newcastle.ac.uk of Kleppel et al. (1989) who showed significant reduc-

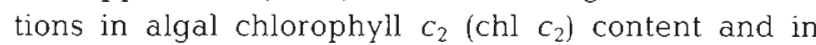
concentrations of the carotenoids peridinin and diadinoxanthin in algae extracted from bleached Montastrea annularis. A decrease in algal chlorophyll content was also reported by Fang et al. (1995) during bleaching induced by exposure of corals to reduced salinity in laboratory studies. No significant changes in algal carotenoid concentrations were noted in these experiments

In the field, predictable solar bleaching events, which result in the formation of localised bleaching areas on coral colonies subject to elevated solar irradiance (Brown et al. 1994), have allowed changes in algal chlorophyll to be monitored by spectrophotometry before, during, and after the bleaching event (Le Tissier \& Brown 1996). In the present paper, changes in algal chlorophyll and carotenoid composition, and measurement of chlorophyll breakdown products have been examined, using HPLC, in the coral Goniastrea aspera during a period of solar bleaching. This type of stress results in bleached areas (solar lesions) on the western surfaces of corals as a result of afternoon subaerial exposure to high solar irradiance (Brown et al. 1994).

Materials and methods. Study site and field sampling: The study site at Phuket, Thailand $\left(7^{\circ} 50^{\prime} \mathrm{N}\right.$, $98^{\circ} 25.5^{\prime} \mathrm{E}$ ), factors responsible for solar bleaching and the temporal progression of bleaching in corals at the site have been described in detail by Brown et al. (1994) and Le Tissier \& Brown (1996). In 1996 a major solar bleaching event was predicted to occur on the spring tide of 17 to 19 February. Coral cores were sampled on 17 February and on 2 consecutive days following initial bleaching. No bleaching was evident 
on 17 February but partially bleached (pale colour) areas were obvious on the western sides of colonies on 18 February and fully bleached (white) solar lesions on 19 February. Cores were extracted by methods described in Le Tissier \& Brown (1996), from normally coloured tissues on the east and west sides of 5 coral colonies on 17 and 19 February and from west sides only on 18 February. Additional cores were collected from partially bleached areas and normally coloured tissues on the west sides of 7 colonies on 18 February, and from fully bleached areas and normally coloured tissues on the west sides of 5 coral colonies on 19 February. Coral cores were transported back to the laboratory on ice in the dark and were stored in a freezer $\left(-20^{\circ} \mathrm{C}\right)$ before processing.

Preparation of samples for HPLC analysis: Cores were air gunned and the tissues collected and homogenised in $10 \mathrm{mM}$ Tris- $\mathrm{HCl}$ and $1 \% \mathrm{NaCl}$ (Sharp et al. 1994) by means of a tissue tearer (Ultra-Turrax T25) at $13500 \mathrm{rpm}$. The skeleton was allowed to settle and the supernatant centrifuged at $600 \times g$ for $10 \mathrm{~min}$. The resulting algal pellets were collected and maintained in liquid nitrogen prior to transportation to the UK. Before HPLC analysis the pellets were homogenised in buffer and subsamples extracted for algal counts; the remaining cells were centrifuged for 5 min at $1800 \times g$ and the resulting pellets extracted in $90 \%$ acetone.

HPLC analysis: Frozen samples were extracted in $90 \%$ acetone and analysed for pigments by reversed phase HPLC on a Pecosphere C-18 column according to Barlow et al. $(1993 \mathrm{~b}, 1995)$. Aliquots of extracts were mixed 1:1 with ammonium acetate buffer and injected into a Shimadzu HPLC system. Two solvents, A and B, were used in the separation. Solvent A consisted of $80 \%$ methanol and $20 \% 1 \mathrm{M}$ ammonium acetate, and solvent B contained $60 \%$ methanol and $40 \%$ acetone. Pigments were separated by a linear gradient from $0 \%$ $\mathrm{B}(100 \% \mathrm{~A})$ to $100 \% \mathrm{~B}(0 \% \mathrm{~A})$ over $10 \mathrm{~min}$ followed by an isocratic hold at $100 \% \mathrm{~B}$ for $7.5 \mathrm{~min}$ at a flow rate of $1 \mathrm{ml} \mathrm{min}^{-1}$ Chlorophylls and carotenoids were monltored by absorbance detection at $440 \mathrm{~nm}$, while phaeopigments were detected by fluorescence at $405 \mathrm{~nm}$ excitation and $670 \mathrm{~nm}$ emission. Pigment identification and calibration were performed with standards obtained from the Water Quality Institute, Denmark, and pigments isolated from microalgal species in the Plymouth Culture Collection (Barlow et al. 1993b, 1995). Peak identity was further confirmed on selected samples by on-line diode-array spectroscopy (Waters 990). Chl $a$ and $b$ standards (Sigma Chemical Co.) were quantified spectrophotometrically using the extinction coefficients of Jeffrey \& Humphrey (1975).

Statistical analysis: Paired t-tests were used for comparing the amount of algal pigments in east and west paired samples and between normally coloured and bleached pairs of cores collected from the same colonies on 18 and 19 February, following the procedure of Zar (1984). On 19 February, the $\alpha$-value was adjusted for the number of multiple comparisons made. The differences computed between paired samples were derived from a normally distributed population of differences and so the assumption for this statistical test was satisfied.

Results. Algal pigment concentrations identified by HPLC are summarised in Table 1 . ChI $a$ and $c_{2}$, the carotenoids peridinin, diadinoxanthin, diatoxanthin and $\beta$-carotene and the chlorophyll breakdown products phaeophytin a and pyrophaeophytin a were recognised in all samples. There were no significant differences in the pigment concentrations of algae from normally coloured tissues extracted from east and west sides of colonies on 17 and 19 February, apart from diatoxanthin which showed significant differences in concentration between east and west sides on 17 February $(p<0.05)$. The mean values of diatoxanthin (Table 1) indicated an increase on the west sides in comparison

Table 1. Concentrations of pigments in $\mathrm{pg}$ cell-1 (standard deviation in parentheses) in samples collected during the bleaching event (17 to 19 February 1996) from east (E) and west (W) sides for normally coloured samples, and from west sides for partially bleached (W-P.bl.) and bleached samples (W-Bl.)

\begin{tabular}{|lccccccc|}
\hline & \multicolumn{2}{c}{17 Feb } & \multicolumn{2}{c}{18 Feb } & & \\
& $E(n=5)$ & $W(n=5)$ & $W(n=7)$ & $W-P . b l .(n=7)$ & $E(n=4)$ & $W(n=5)$ & $W-B 1 .(n=5)$ \\
\hline Chlorophyll a & $5.46(1.42)$ & $5.01(0.71)$ & $4.78(2.15)$ & $1.96(1.24)$ & $6.37(1.39)$ & $4.23(1.84)$ & $1.09(0.70)$ \\
Chlorophyll $C_{2}$ & $1.17(0.29)$ & $1.11(0.14)$ & $1.02(0.44)$ & $0.40(0.32)$ & $1.43(0.44)$ & $0.92(0.39)$ & $0.18(0.17)$ \\
Peridinin & $3.06(0.84)$ & $2.89(0.54)$ & $2.64(1.12)$ & $1.14(0.74)$ & $3.56(0.92)$ & $2.50(0.93)$ & $0.62(0.49)$ \\
Diadinoxanthin (Dd) & $1.15(0.32)$ & $0.89(0.05)$ & $0.94(0.40)$ & $0.45(0.29)$ & $1.25(0.29)$ & $0.85(0.38)$ & $0.31(0.22)$ \\
Diatoxanthin (Dt) & $0.17(0.04)$ & $0.40(0.14)$ & $0.28(0.13)$ & $0.23(0.05)$ & $0.15(0.04)$ & $0.26(0.04)$ & $0.18(0.12)$ \\
$\beta$ B-Carotene & $0.12(0.03)$ & $0.12(0.03)$ & $0.12(0.05)$ & $0.08(0.03)$ & $0.15(0.04)$ & $0.12(0.03)$ & $0.08(0.04)$ \\
Dt/(Dd+Dt) & $0.13(0.03)$ & $0.30(0.07)$ & $0.23(0.05)$ & $0.37(0.08)$ & $0.11(0.00)$ & $0.25(0.08)$ & $0.38(0.05)$ \\
Phaeophytin a & $0.03(0.02)$ & $0.03(0.01)$ & $0.09(0.07)$ & $0.29(0.23)$ & $0.05(0.03)$ & $0.13(0.13)$ & $0.41(0.13)$ \\
Pyrophaeophytin a & $0.01(0.01)$ & $0.03(0.01)$ & $0.02(0.02)$ & $0.09(0.06)$ & $0.02(0.01)$ & $0.04(0.04)$ & $0.15(0.05)$ \\
\hline
\end{tabular}


to the east sides. The ratio of diatoxanthin to the total xanthophyll pool (i.e. diatoxanthin plus diadinoxanthin) was also significantly different $(p<0.005)$ between east and west sides of colonies sampled on both 17 and 19 February, with west sides showing higher ratios compared to east sides by approximately 2 -fold.

On subsequent days (18 and 19 February), significant differences in chlorophyll pigments between normally coloured tissues and partially bleached $(p<0.05)$ and fully bleached $(\mathrm{p}<0.01)$ tissues on the west sides of colonies were noted. Both partially bleached and fully bleached tissues contained algae with decreased chlorophyll pigment values compared to normally coloured tissues. In parallel with these alterations, an increase in the concentration of chlorophyll breakdown products in partially bleached and bleached areas (compared to normally coloured tissues on the western sides of colonies) was evident. A simple chlorophyll budget was calculated (after Barlow et al. 1993a) by using estimates of the molar ratio of chlorophyll and its breakdown products for partially bleached (18 February) and fully bleached samples (19 February) compared with normally coloured tissues extracted from western surfaces on these dates (Fig. 1). Approximately $45 \%$ of chl a was lost, presumably as a colourless residue, in partially bleached tissues with approximately $62 \%$ lost in fully bleached tissues. In these latter samples, $10 \%$ chl a was converted into phaeophytin a and $4 \%$ into pyrophaeophytin $a$.

Comparison of algal carotenoid concentrations between bleached tissues and normally coloured tissues revealed decreased mean values for peridinin $(\mathrm{p}<$ 0.01 ) in bleached samples. Increases in the ratio of diatoxanthin to the total xanthophyll pool were apparent in partially bleached $(p<0.001)$, but not in fully bleached, tissues. No significant differences in the concentration of $\beta$-carotene in different tissues were observed. The carotenoid composition of partially bleached and fully bleached tissues from the west sides of colonies is compared with that of normally coloured coral samples in Fig. 2. The major differences between the samples relate to the size of the xanthophyll pool components, diadinoxanthin and diatoxanthin, which are greatest in the fully bleached tissues sampled on 19 February. $\beta$-Carotene is also present in greater proportions in fully bleached tissues than in normally coloured and partially bleached tissues.

Discussion. Significant reductions in algal chl $a$ and $c_{2}$ and the light-harvesting accessory pigment peridinin were observed in partially and fully bleached tissues following solar bleaching, when compared with normally coloured tissues from the western surfaces of colonies. Previous studies of bleached corals from the Caribbean, by HPLC, detected reduced chl $c_{2}$ and

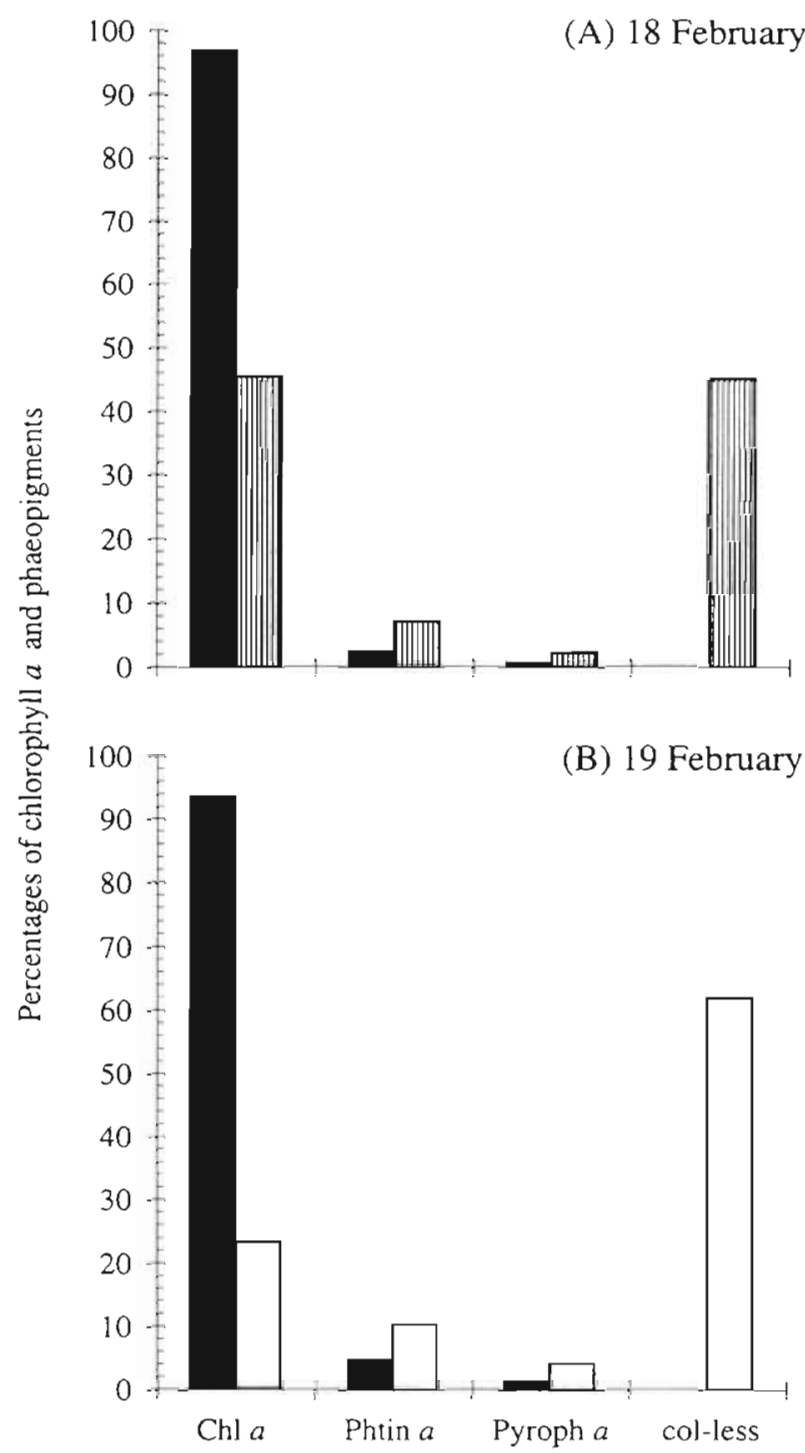

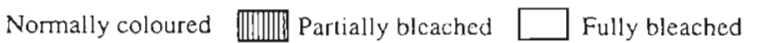

Fig. 1. Proportion of chlorophyll a and its breakdown products in normally coloured, partially bleached and bleached samples from the west sides of coral colonies collected on 18 and 19 February. Pigment identities are: Chl a, chlorophyll a; Phtin a, phaeophytin a; Pyroph a, pyrophaeophytin a; col-less, colourless products

peridinin levels in algae but no attempts were made to analyse chlorophyll breakdown products (Kleppel et al. 1989). The present study is the first to identify chlorophyll breakdown products in symbiotic algae of bleached coral tissues. Phaeophytin a is produced in vitro by acidification (Lorenzen 1967) while enzymatically mediated pyrolysis of phaeophytin a may be responsible for the production of pyrophaeophytin a (Barlow et al. 1993a). The mechanism for specific production of phaeopigments in vivo remains unknown. 
(A) Normally coloured

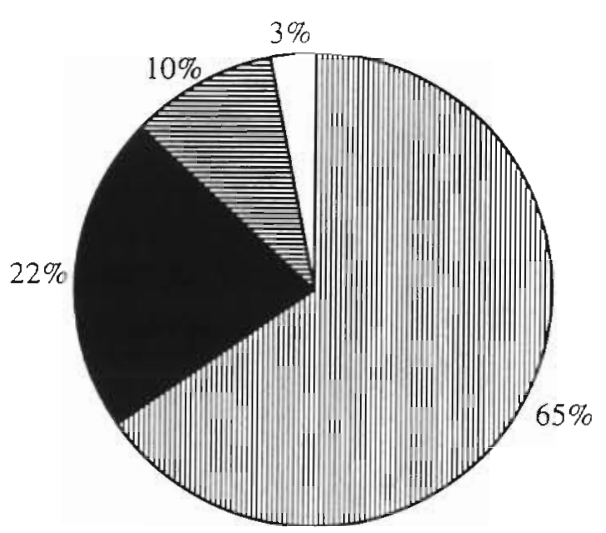

(B) Partially bleached

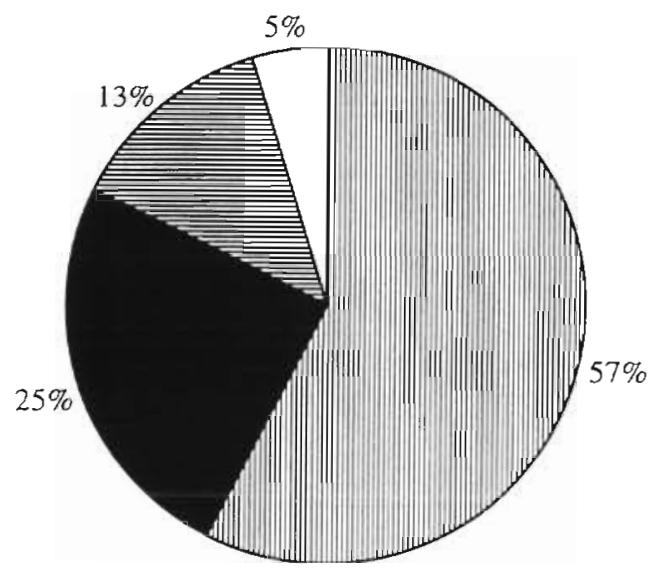

(C) Fully bleached

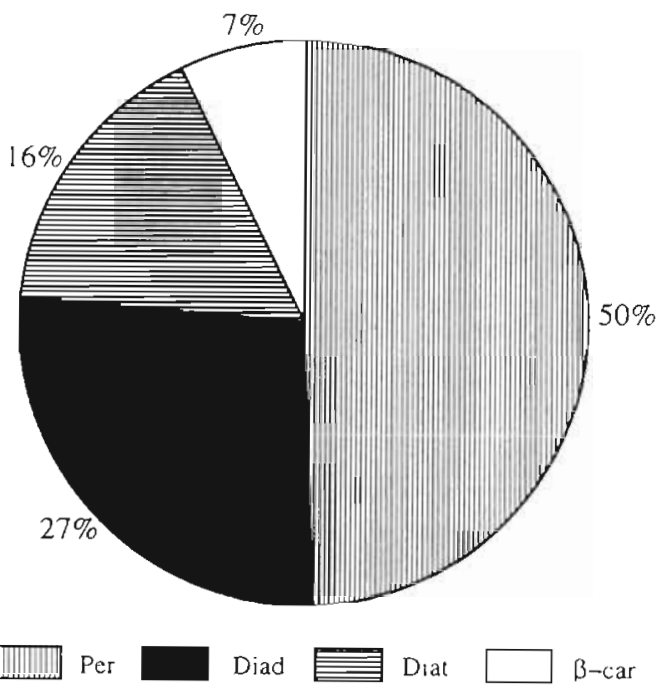

Fig. 2. Carotenoid composition as percentage of total carotenold content of (A) normally coloured, (B) partially bleached. and (C) fully bleached coral samples. The relative size of the pie diagrams reflects the difference in total content of the carotenoids (on a chlorophyll $a+c_{2}$ basis) between the samples. Pigment identities are: Per, peridinin; Diad, diadinoxanthin; Diat, diatoxanthin; $\beta$-car, $\beta$-carotene
The degradation of chl $\alpha$ and the resulting formation of breakdown products under conditions of high irradiance has been well documented in higher plants (Brown et al. 1991) but the mechanism of chlorophyll breakdown in bleached corals is unknown. Although the majority of coral bleaching responses have been correlated with elevated temperatures, increasing physiological and field evidence points to an interaction between elevated temperature and irradiance as a major factor in the extensive bleaching of corals worldwide over the past 15 yr (Glynn 1993. Brown et al. 1995, Brown 1997, Iglesias Prieto \& Trench 1997). For corals subject to solar bleaching in the present study, the generation of colourless residues within $24 \mathrm{~h}$ of exposure to high irradiance suggests a very rapid photodegradation of chlorophyll (Jen \& Mackinney 1970). Such colourless residues are produced in higher plants in the presence of active oxygen radicals (Brown et al. 1991) which have already been invoked as mediators of the bleaching process in symbiotic anthozoans, subject to elevated temperatures and irradiance (Lesser et al 1990).

Also of interest in the present study is the possible photoprotective role of the algal xanthophylls diatoxanthin and diadinoxanthin. The conversion of diadinoxanthin to diatoxanthin in the light and the resulting dissipation of excess absorbed light energy as heat has been cited as having a photoprotective role in algae (Demers et al. 1991, Arsalane et al. 1994, Young \& Frank 1996) similar to that of the well established xanthophyll cycle in higher plants (Demmig-Adams \& Adams 1993). Increased production of diatoxanthin in algae extracted from the western surfaces of corals subjected to high levels of solar radiation, the increase in the ratio of diatoxanthin to the total xanthophyll pool in bleached tissues and the progressive increase in the total xanthophyll pool over the bleaching period (relative to total chlorophyll levels) all support a potential photoprotective function for diadinoxanthin and diatoxanthin in the coral/algal symbiosis. A progressive increase in $\beta$-carotene proportions in bleached tissues over the bleaching period bears similarities with higher plants where the xanthophyll cycle pool and $\beta$-carotene have been reported to vary concomitantly (Demmig-Adams et al. 1989. Thayer \& Bjorkman 1990). The fact that corals were bleached on the western surfaces of colonies suggests that any photoprotective function was stretched to its limits and, in the case of the bleached tissues, defense mechanisms failed ultimately to offer algal cells adequate protection from the damaging effects of solar radiation.

Carotenoids in symbiotic algae clearly have the potential of playing an important role in the coral bleaching process. Already Warner et al. (1996) have shown that symbiotic algae from different coral species 
vary in their photoprotective ability and that this characteristic is correlated with their susceptibility to bleaching at elevated temperatures. Such an ability is most likely influenced by the efficiency of the xanthophyll cycle and the size of the xanthophyll pool, but more detailed study of carotenoids is needed before the significance of the photoprotective function of the xanthophylls can be established in the coral/algal symbiosis. It should be noted that while diadinoxanthin and diatoxanthin have been identified in coral symbiotic algae, the presence of an active xanthophyll cycle can only be demonstrated by complementary studies of algal photosynthetic efficiency under high irradiance stress and recovery. Furthermore differences in photoprotective ability are most likely correlated not only with the presence of the xanthophyll cycle but also with a suite of important mechanisms that include morphological changes in the chloroplasts, presence and activity of antioxidant enzymes and ability to repair photochemical damage

Acknowledgements. We thank the Director and staff of the Phuket Marine Biological Centre for their support, particularly Dr Hansa Chansang, Mr Niphon Phongsuwan, and Mr Ukkrit Satapoomin.

\section{LITERATURE CITED}

Arsalane W, Rousseau, Duval JC (1994) Influence of the pool size of the xanthophyll cycle on the effects of light stress in a diatom-competition between photoprotection and photoinhibition. Photochem Photobiol 60:237-243

Barlow RG, Mantoura RFC, Gough MA, Fileman TW (1993a) Phaeopigment distribution during the 1990 spring bloom in the northeastern Atlantic. Deep Sea Res I 40:2229-2242

Barlow RG, Mantoura RFC, Gough MA, Fileman TW (1993b) Pigment signatures of the phytoplankton composition in the northeastern Atlantic during the 1990 spring bloom. Deep Sea Res II 40:459-477

Barlow RG, Mantoura RFC, Peinert RD, Miller AEJ, Fileman TW (1995) Distribution, sedimentation and fate of pigment biomarkers following thermal stratification in the western Alboran Sea. Mar Ecol Prog Ser 125:279-291

Brown BE (1997) Coral bleaching: causes and consequences. Coral Reefs 16(5):129-138

Brown BE, Dunne RP, Scoffin TP, Le Tissier MDA (1994) Solar damage in intertidal corals. Mar Ecol Prog Ser 105 $219-230$

Brown BE, Le Tissier MDA, Bythell TC (1995) Mechanisms of bleaching deduced from histological studies of reef corals sampled during a natural bleaching event. Mar Biol 122 $655-663$

Brown SB, Houghton JD. Hendry GAF (1991) Chlorophyll breakdown. In: Scheer H (ed) The chlorophylls. CRC Press, Boca Raton, p 465-489

Demers S, Roy S, Gagnon R, Vignault C (1991) Rapid lightinduced changes in cell fluorescence and in xanthophyllcycle pigments of Alexandrium excavatum (Dinophyceae) and Thalassiosira pseudonana (Bacillariophyceae): a photoprotection mechanism. Mar Ecol Prog Ser 76:185-193
Demmig-Adams B, Adams WW III (1993) The xanthophyll cycle. In: Young AJ, Britton G (eds) Carotenolds in photosynthesis. Chapman \& Hall, 1 ondon, p 206-251

Demmig-Adams $B$, Winter $K$, Winkelmann E, Kruger $A$, Czygan FC (1989) Photosynthetic characteristics and the ratios of chlorophyll, $\beta$-carotene, and the components of the xanthophyll cycle upon a sudden increase in growth light regime in several plant species. Bot Acta 102(4): $319-325$

Fang LS, Liao CW, Liu MC (1995) Pigment composition in different-colored scleractinian corals before and during the bleaching process. Zool Stud 34(1):10-17

Fitt WK, Spero HJ, Halas J, White MW, Porter JW (1993) Recovery of the coral Montastrea annularis in the Florida Keys after the 1987 Carbbean 'bleaching event' Coral Reefs 12(2):57-64

Glynn PW (1993) Coral-reef bleaching-ecological perspectives. Coral Reefs 12(1):1-17

Hoegh-Guldberg O, Smith GJ (1989) The effect of sudden changes in temperature, light, and salinity on the populatron density and export of zooxanthellae from the reef Stylophora pistillata Esper and Seriatopora hystrix Dana. J Exp Mar Biol Ecol 129:279-303

Iglesias Prieto J, Trench RK (1997) Photoadaptation, photoacclimation and niche diversification in invertebratedinoflagellate symbioses. Proc 8th Int Coral Reef Symp. Panama (in press)

Jeffrey SW, Humphrey GP (1975) New spectrophotometric equations for determining chlorophylls $\mathrm{a}, \mathrm{b}$, and $\mathrm{c} 1$ and $\mathrm{c2}$ in higher plants, algae and natural phytoplankton. Biochem Physiol Pflanz 167:191-194

Jen JJ, Mackinney G (1970) On the photodecomposition of chlorophyll in vitro-I reaction rates. Photochem Photobiol 11:297-302

Kleppel GS, Dodge RE, Reese CJ (1989) Changes in pigmentation associated with the bleaching of stony corals. Limnol Oceanogr 34:1331-1335

Lesser MP, Stochaj WR, Tapley DW, Shick JM (1990) Bleaching in coral reef anthozoans: effects of irradiance, ultravolet radiation, and temperature on the activities of protective enzymes against active oxygen. Coral Reefs 8 . $225-232$

Le Tissier MDA, Brown BE (1996) Dynamics of solar bleaching in the intertidal reef coral Goniastrea aspera at Ko Phuket, Thailand. Mar Ecol Prog Ser 136:235-244

Lorenzen CJ (1967) Determination of chlorophyll and phaeopigments: spectrophotometric equations. Limnol Oceanogr $12: 343-346$

Sharp VA, Miller D, Bythell JC, Brown BE (1994) Expression of low molecular weight hsp 70 related polypeptides from the symbiotic sea anemone Anemonia viridis Forskál in response to heat shock. J Exp Mar Biol Ecol 179:179-193

Szmant AM, Gassman NJ (1990) The effects of prolonged bleaching on the tissue biomass and reproduction of the reef coral Montastred annularis. Coral Reefs 8:217-224

Thayer SS, Bjorkman O (1990) Leaf xanthophyll content and composition in sun and shade determined by HPLC. Photosynth Res 23(3):331-343

Warner ME, Fitt WK Schmidt GW (1996) The effects of elevated temperature on the photosynthetic efficiency of zooxanthellae in hospite from four different species of reef coral - a novel approach. Plant Cell Environ 19(3):291-299

Young AJ, Frank HA (1996) Energy transfer reactions involving carotenoids: quenching of chlorophyll fluorescence. Photochem Photobiol 36:3-15

Zar JH (1984) Biostatistical analysis. Prentice-Hall, Englewood Cliffs, NJ 